\title{
Effect of Zinc and Boron on Nutrient Uptake, Yield and Quality of Mustard under Rainfed Condition
}

\author{
Shanoor Nadaf and H.T. Chandranath* \\ Department of Agronomy, University of Agricultural Sciences, \\ Dharwad-580 005, Karnataka, India \\ *Corresponding author
}

\section{A B S T R A C T}

\section{Keywords}

Zinc, Boron,

Mustard, Yield, Oil content, Uptake

Article Info

Accepted:

18 May 2019

Available Online:

10 June 2019
A field experiment was conducted to study the effect of zinc and boron levels on yield, quality and nutrient uptake in mustard under Northern transition zone of Karnataka during rabi, 2017 at MARS, UAS, Dharwad with 10 treatments. The treatment comprised of two levels of zinc $\left(10 \mathrm{~kg} \mathrm{ha}^{-1}\right.$ and $\left.20 \mathrm{~kg} \mathrm{ha}^{-1}\right)$ and two levels of boron $\left(1 \mathrm{~kg} \mathrm{ha}^{-1}\right.$ and $\left.2 \mathrm{~kg} \mathrm{ha}^{-1}\right)$ and their combinations. These treatments were compared with RDF + FYM @ $5 \mathrm{t} \mathrm{ha}^{-1}$ and RDF (60:50:40 N: $\mathrm{P}_{2} \mathrm{O}_{5}: \mathrm{K}_{2} \mathrm{O}$ ) alone. The treatments were replicated thrice in a randomized block design. The experimental soil being deficient in zinc and boron, good response of crop to the applied zinc and boron was noticed. Application of $\mathrm{ZnSO}_{4} @ 20 \mathrm{~kg}$ ha $^{-1}$ along with borax @ $2 \mathrm{~kg} \mathrm{ha}^{-1}$ recorded higher seed yield (1973 kg ha $\left.{ }^{-1}\right)$, oil content $(37.08 \%)$, oil yield $\left(731 \mathrm{~kg} \mathrm{ha}^{-1}\right)$, uptake of zinc $\left(242 \mathrm{~g} \mathrm{ha}^{-1}\right)$ and boron $\left(76 \mathrm{~g} \mathrm{ha}^{-1}\right)$ were noticed over RDF + FYM alone. However which was on par with application of RDF + $\mathrm{ZnSO}_{4} @ 20 \mathrm{~kg} \mathrm{ha}^{-1}+$ Borax @1 kg ha ${ }^{-1}$ and RDF+ ZnSO $\mathrm{Zn}_{4} @ 10 \mathrm{~kg} \mathrm{ha}^{-1}+$ Borax @ 2 kg $\mathrm{ha}^{-1}$

\section{Introduction}

Mustard (Brassica juncea L.) is an important edible oilseed crop in India. Area, production and productivity of mustard is 5.74 million hectares, 6.28 million tonnes and $1,183 \mathrm{~kg}$ ha ${ }^{1}$ respectively. In Karnataka area, production and productivity of mustard is 0.02 million hectares, 1.00 million tonnes and $500 \mathrm{~kg} \mathrm{ha}^{-1}$ respectively (Anon., 2017). The Karnataka productivity is quite lower than national average. The gap between production and demand of oilseeds is progressively widening, therefore, the production of oilseeds is to be increased for self-sufficiency. The total nutrients absorbed by a crop producing 4.5 tonnes of seed per hectare are of the order (in kilograms): $\mathrm{N}$ 300-350, $\mathrm{P}_{2} \mathrm{O}_{5}$ 120-140, $\mathrm{K}_{2} \mathrm{O}$ 300-400, Zn- $100 \mathrm{~g}$ and B-36 g. Available zinc status in black and red soils was deficient in the major portion of the northern transition zone of Karnataka (Pulakeshi et al., 2012). Since, the soils are alkaline and rich in $\mathrm{CaCO}_{3}$, zinc may be precipitated as hydroxides and carbonates under alkaline $\mathrm{pH}$ range. Therefore, their solubility and mobility may be decreased resulting in reduced availability. 
Micronutrients are as important to plant nutrition as primary and secondary nutrients, though plants don't require as much of them. Lack of any one of the micronutrients in the soil can limit growth, even when all other nutrients are present in adequate amounts. High yielding mustard crop removes more micronutrients from the soil which cannot be replenished from the use of high analysis NPK fertilizers containing lower quantities of micronutrient contaminants. So, there is need for micronutrients application in order to achieve balanced nutrition. Thus, there is an urgent need for stepping up the use of micronutrients in growing field crops.

Every micronutrient has specific role to play in plant physiology and its presence in optimum concentration in plant to complete its life cycle. The deficiencies of micronutrients viz., $\mathrm{Zn}$ and $\mathrm{B}$ were increased day to day due to imbalance application of nutrients. The research information on response of mustard to zinc and boron application is lacking especially in northern transition zone of Karnataka. In this context the present investigation entitled with "Effect of zinc and boron levels on nutrient uptake, yield and quality of mustard".

\section{Materials and Methods}

A field experiment was conducted to study the effect of zinc and boron levels on yield, quality and nutrient uptake in mustard under Northern transition zone of Karnataka during rabi, 2017 at MARS, UAS, Dharwad with 10 treatments. The treatment comprised of two levels of zinc $\left(10 \mathrm{~kg} \mathrm{ha}^{-1}\right.$ and $\left.20 \mathrm{~kg} \mathrm{ha}^{-1}\right)$ and two levels of boron $\left(1 \mathrm{~kg} \mathrm{ha}^{-1}\right.$ and $\left.2 \mathrm{~kg} \mathrm{ha}^{-1}\right)$ and their combinations. These treatments were compared with RDF + FYM @ $5 \mathrm{t} \mathrm{ha}^{-1}$ and RDF alone. The treatments were replicated thrice in a randomized block design. The concentration of zinc in the digested plant samples was determined after proper dilution using atomic absorption spectrophotometer (Jackson, 1973). The boron in plant sample was estimated by dry ashing which was extracted with $0.5 \mathrm{M} \mathrm{HCl}$. The boron in the aliquot was determined by Azomethine-H method using spectrophotometer at $420 \mathrm{~nm}$ (Singh et al., 2010). The oil content of seed estimated in twelve grams of dried seeds of mustard drawn from the net plot of each treatment were used for estimation of oil content by Nuclear Magnetic Resonance (NMR) method and expressed in percentage. The instrument used is Nuclear Magnetic Resonance Spectrometry. The NMR technique measures the resonance of energy absorbed by the hydrogen atoms in the sample. Usually oil contents are expressed based on specific moisture content basis (\%). Using the NMR in measuring oil content is referenced by ISO 10565: 1998 Oilseeds.

\section{Results and Discussion}

\section{Seed, stalk yield and harvest index of mustard}

Seed yield, stalk yield and harvest index of mustard were significantly influenced by zinc and boron levels on mustard (Table 1). Among the different micronutrient levels, seed yield (1973 $\mathrm{kg} \mathrm{ha}^{-1}$ ) was significantly higher with the application of RDF + FYM+ $\mathrm{ZnSO}_{4} @ 20 \mathrm{~kg} \mathrm{ha}^{-1}+$ Borax @ 2 kg ha ${ }^{-1}$ which was on par with $\mathrm{RDF}+\mathrm{FYM}+\mathrm{ZnSO}_{4}$ @ $20 \mathrm{~kg} \mathrm{ha}^{-1}+$ Borax @ $1 \mathrm{~kg} \mathrm{ha}^{-1}$ (1940 kg ha$\left.{ }^{1}\right)$ and $\mathrm{RDF}+\mathrm{FYM}+\mathrm{ZnSO}_{4} @ 10 \mathrm{~kg} \mathrm{ha}^{-1}+$ Borax@ $2 \mathrm{~kg} \mathrm{ha}^{-1}$ (1929 kg ha $\left.{ }^{-1}\right)$ compared to RDF alone (1473 kg ha $\left.{ }^{-1}\right)$. The higher seed yield recorded with application of $\mathrm{ZnSO}_{4}$ and borax might have met the crop demand for zinc and boron at right time when pollen tubes were to be developed, which may result in increased pollen germination and pollen viability and translocation of photosynthates towards sink that due improved the seed setting percentage in the siliqua of mustard. 
Table.1 Seed yield, stalk yield and harvest index of mustard as influenced by levels of zinc and boron

\begin{tabular}{|c|c|c|c|}
\hline Treatment & $\begin{array}{l}\text { Seed yield } \\
\left(\mathrm{kg} \mathrm{ha}^{-1}\right)\end{array}$ & $\begin{array}{l}\text { Stalk yield } \\
\left(\mathrm{kg} \mathrm{ha}^{-1}\right)\end{array}$ & $\begin{array}{l}\text { Harvest index } \\
(\%)\end{array}$ \\
\hline $\mathrm{T}_{1}$ : RDF only & 1,473 & 4,415 & 25.03 \\
\hline $\mathrm{T}_{2}: \mathrm{RDF}+\mathrm{FYM}$ & 1,543 & 4,552 & 25.30 \\
\hline $\mathrm{T}_{3}: \mathrm{RDF}+\mathrm{FYM}+$ Borax @ $1 \mathrm{~kg} \mathrm{ha}^{-1}$ & 1,655 & 4,801 & 25.63 \\
\hline $\mathrm{T}_{4}: \mathrm{RDF}+\mathrm{FYM}+$ Borax @ $2 \mathrm{~kg} \mathrm{ha}^{-1}$ & 1,757 & 4,903 & 26.39 \\
\hline $\mathrm{T}_{5}: \mathrm{RDF}+\mathrm{FYM}+\mathrm{ZnSO}_{4} @ 10 \mathrm{~kg} \mathrm{ha}^{-1}$ & 1,766 & 4,918 & 26.39 \\
\hline $\mathrm{T}_{6}: \mathrm{RDF}+\mathrm{FYM}+\mathrm{ZnSO}_{4} @ 20 \mathrm{~kg} \mathrm{ha}^{-1}$ & 1,834 & 4,986 & 26.91 \\
\hline $\mathrm{T}_{7}: \mathrm{RDF}+\mathrm{FYM}+\mathrm{ZnSO}_{4} @ 10 \mathrm{~kg} \mathrm{ha}^{-1}+$ Borax @ $1 \mathrm{~kg} \mathrm{ha}^{-1}$ & 1,847 & 5,000 & 26.97 \\
\hline $\mathrm{T}_{8}: \mathrm{RDF}+\mathrm{FYM}+\mathrm{ZnSO}_{4} @ 10 \mathrm{~kg} \mathrm{ha}^{-1}+$ Borax @ $2 \mathrm{~kg} \mathrm{ha}^{-1}$ & 1,929 & 5,081 & 27.49 \\
\hline $\mathrm{T}_{9}: \mathrm{RDF}+\mathrm{FYM}+\mathrm{ZnSO}_{4} @ 20 \mathrm{~kg} \mathrm{ha}^{-1}+$ Borax @ $1 \mathrm{~kg} \mathrm{ha}^{-1}$ & 1,940 & 5,092 & 27.61 \\
\hline $\mathrm{T}_{10}: \mathrm{RDF}+\mathrm{FYM}+\mathrm{ZnSO}_{4} @ 20 \mathrm{~kg} \mathrm{ha}^{-1}+$ Borax @ $2 \mathrm{~kg} \mathrm{ha}^{-1}$ & 1,973 & 5,125 & 27.78 \\
\hline S.Em. \pm & 34.07 & 119.29 & 0.49 \\
\hline C.D. $(p=0.05)$ & 101.23 & 354.44 & 1.47 \\
\hline
\end{tabular}

* Note: RDF 60:50:40 N: $\mathrm{P}_{2} \mathrm{O}_{5}: \mathrm{K}_{2} \mathrm{O} \mathrm{kg} \mathrm{ha}{ }^{-1}$ along with FYM $\left(5 \mathrm{t} \mathrm{ha}^{-1}\right)$ was applied to all the treatments except $\mathrm{T}_{1}$, DAS- Days after sowing.

Table.2 Zinc and boron uptake as influenced by levels of zinc and boron

\begin{tabular}{|c|c|c|c|c|c|c|}
\hline \multirow[t]{2}{*}{ Treatment } & \multicolumn{3}{|c|}{ Zinc $\left(\mathrm{g} \mathrm{ha}^{-1}\right)$} & \multicolumn{3}{|c|}{ Boron $\left(\mathrm{g} \mathrm{ha}^{-1}\right)$} \\
\hline & Seed & Stalk & Total & Seed & Stalk & Total \\
\hline$T_{1}$ : RDF only & 50.44 & 88.92 & 139.35 & 15.35 & 24.62 & 39.98 \\
\hline $\mathrm{T}_{2}: \mathrm{RDF}+\mathrm{FYM}$ & 58.44 & 107.20 & 165.64 & 20.74 & 31.88 & 52.62 \\
\hline$T_{3}:$ RDF + FYM + Borax @ $1 \mathrm{~kg} \mathrm{ha}^{-1}$ & 61.35 & 116.18 & 177.53 & 22.58 & 40.32 & 62.90 \\
\hline $\mathrm{T}_{4}: \mathrm{RDF}+\mathrm{FYM}+$ Borax @ $2 \mathrm{~kg} \mathrm{ha}^{-1}$ & 67.10 & 121.56 & 188.66 & 23.87 & 44.45 & 68.32 \\
\hline $\mathrm{T}_{5}: \mathrm{RDF}+\mathrm{FYM}+\mathrm{ZnSO}_{4} @ 10 \mathrm{~kg} \mathrm{ha}^{-1}$ & 68.41 & 123.19 & 191.60 & 24.05 & 44.66 & 68.71 \\
\hline $\mathrm{T}_{6}: \mathrm{RDF}+\mathrm{FYM}+\mathrm{ZnSO}_{4} @ 20 \mathrm{~kg} \mathrm{ha}^{-1}$ & 71.23 & 152.96 & 224.19 & 25.07 & 46.18 & 71.25 \\
\hline $\mathrm{T}_{7}: \mathrm{RDF}+\mathrm{FYM}+\mathrm{ZnSO}_{4} @ 10 \mathrm{~kg} \mathrm{ha}^{-1}+$ Borax @ $1 \mathrm{~kg} \mathrm{ha}^{-1}$ & 72.58 & 155.58 & 228.16 & 25.28 & 46.38 & 71.66 \\
\hline $\mathrm{T}_{8}: \mathrm{RDF}+\mathrm{FYM}+\mathrm{ZnSO}_{4} @ 10 \mathrm{~kg} \mathrm{ha}^{-1}+$ Borax @ $2 \mathrm{~kg} \mathrm{ha}^{-1}$ & 76.07 & 159.84 & 235.91 & 28.15 & 47.20 & 75.35 \\
\hline $\mathrm{T}_{9}: \mathrm{RDF}+\mathrm{FYM}+\mathrm{ZnSO}_{4} @ 20 \mathrm{~kg} \mathrm{ha}^{-1}+$ Borax @ $1 \mathrm{~kg} \mathrm{ha}^{-1}$ & 76.06 & 161.68 & 237.74 & 28.64 & 47.41 & 76.05 \\
\hline $\mathrm{T}_{10}: \mathrm{RDF}+\mathrm{FYM}+\mathrm{ZnSO}_{4} @ 20 \mathrm{~kg} \mathrm{ha}^{-1}+$ Borax @ $2 \mathrm{~kg} \mathrm{ha}^{-1}$ & 77.30 & 165.41 & 242.71 & 29.04 & 47.69 & 76.74 \\
\hline S.Em. \pm & 2.36 & 6.76 & 8.11 & 0.56 & 1.41 & 1.50 \\
\hline C.D. $(p=0.05)$ & 7.01 & 20.07 & 24.08 & 1.67 & 4.20 & 4.45 \\
\hline
\end{tabular}

* Note: RDF 60:50:40 N: $\mathrm{P}_{2} \mathrm{O}_{5}: \mathrm{K}_{2} \mathrm{O} \mathrm{kg} \mathrm{ha}{ }^{-1}$ along with FYM $\left(5 \mathrm{t} \mathrm{ha}^{-1}\right)$ was applied to all the treatments except $\mathrm{T}_{1}$, DAS- Days after sowing. 
Table.3 Oil content and oil yield of mustard as influenced by levels of zinc and boron

\begin{tabular}{|c|c|c|}
\hline Treatment & Oil content (\%) & Oil yield $\left(\mathrm{kg} \mathrm{ha}^{-1}\right)$ \\
\hline $\mathrm{T}_{1}$ : RDF only & 35.56 & 524 \\
\hline$T_{2}:$ RDF + FYM & 35.63 & 550 \\
\hline $\mathrm{T}_{3}: \mathrm{RDF}+\mathrm{FYM}+$ Borax @ $1 \mathrm{~kg} \mathrm{ha}^{-1}$ & 35.65 & 589 \\
\hline $\mathrm{T}_{4}: \mathrm{RDF}+\mathrm{FYM}+$ Borax @ $2 \mathrm{~kg} \mathrm{ha}^{-1}$ & 35.66 & 627 \\
\hline $\mathrm{T}_{5}: \mathrm{RDF}+\mathrm{FYM}+\mathrm{ZnSO}_{4} @ 10 \mathrm{~kg} \mathrm{ha}^{-1}$ & 35.83 & 632 \\
\hline $\mathrm{T}_{6}: \mathrm{RDF}+\mathrm{FYM}+\mathrm{ZnSO}_{4} @ 20 \mathrm{~kg} \mathrm{ha}^{-1}$ & 35.84 & 657 \\
\hline $\mathrm{T}_{7}: \mathrm{RDF}+\mathrm{FYM}+\mathrm{ZnSO}_{4} @ 10 \mathrm{~kg} \mathrm{ha}^{-1}+$ Borax @ $1 \mathrm{~kg} \mathrm{ha}^{-1}$ & 36.73 & 678 \\
\hline 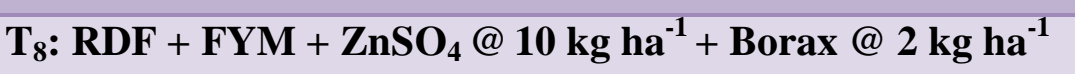 & 37.03 & 714 \\
\hline $\mathrm{T}_{9}: \mathrm{RDF}+\mathrm{FYM}+\mathrm{ZnSO}_{4} @ 20 \mathrm{~kg} \mathrm{ha}^{-1}+$ Borax $@ 1 \mathrm{~kg} \mathrm{ha}^{-1}$ & 37.06 & 718 \\
\hline $\mathrm{T}_{10}: \mathrm{RDF}+\mathrm{FYM}+\mathrm{ZnSO}_{4} @ 20 \mathrm{~kg} \mathrm{ha}^{-1}+$ Borax $@ 2 \mathrm{~kg} \mathrm{ha}^{-1}$ & 37.08 & 731 \\
\hline S.Em. \pm & 0.37 & 12 \\
\hline C.D. $(p=0.05)$ & 1.11 & 35 \\
\hline
\end{tabular}

* Note: $\mathrm{RDF}$ 60:50:40 N: $\mathrm{P}_{2} \mathrm{O}_{5}: \mathrm{K}_{2} \mathrm{O} \mathrm{kg} \mathrm{ha}{ }^{-1}$ along with FYM $\left(5 \mathrm{t} \mathrm{ha}^{-1}\right)$ was applied to all the treatments except $\mathrm{T}_{1}$, DAS- Days after sowing. 
Similar types of results were found by Rani and Reddy (1993) and Tamak et al., (1997) in mustard. The stalk yield of mustard was also significantly influenced by zinc and boron levels (Table 1). Among different treatments, application $\mathrm{RDF}+\mathrm{FYM}+\mathrm{ZnSO}_{4} @ 20 \mathrm{~kg}$ ha 1 + Borax @2 kg ha ${ }^{-1}$ at harvest recorded significantly higher stalk yield (5125 kg ha-1) which was on par with application of RDF + $\mathrm{FYM}+\mathrm{ZnSO}_{4} @ 20 \mathrm{~kg} \mathrm{ha}^{-1}+$ Borax @ $1 \mathrm{~kg}$ $\mathrm{ha}^{-1}\left(5092 \mathrm{~kg} \mathrm{ha}^{-1}\right), \mathrm{RDF}+\mathrm{FYM}+\mathrm{ZnSO}_{4} @$ $10 \mathrm{~kg} \mathrm{ha}^{-1}+$ Borax @ $2 \mathrm{~kg} \mathrm{ha}^{-1}\left(5081 \mathrm{~kg} \mathrm{ha}^{-1}\right)$ and RDF + FYM + $\mathrm{ZnSO}_{4} @ 10 \mathrm{~kg} \mathrm{ha}^{-1}+$ Borax@1 kg ha ${ }^{-1}\left(5000 \mathrm{~kg} \mathrm{ha}^{-1}\right)$ at harvest. This was mainly due to zinc and boron role in increasing photosynthesis which resulted in higher growth and development. Same results were also reported by Shaker and Mohammed (2011) in mustard.

Significantly higher harvest index $(27.78 \%)$ of mustard was recorded with the application of $\mathrm{RDF}+\mathrm{FYM}+\mathrm{ZnSO}_{4} @ 20 \mathrm{~kg} \mathrm{ha}^{-1}+$ Borax@2 kg ha ${ }^{-1}$ at harvest. Significantly lower harvest index $(25.03 \%)$ observed with application of RDF only. The increase in harvest index may be attributed to better utilization of photo-assimilates for seed formation. Similar results have been discussed by Venkatakrishnan and Balasubramaniam (1996).

\section{Uptake of zinc and boron by mustard}

In the present study, among different treatments, higher uptake of zinc in seed $(77 \mathrm{~g}$ $\mathrm{ha}^{-1}$ ) and stalk (165 $\left.\mathrm{g} \mathrm{ha}^{-1}\right)$ by mustard crop at harvest was significantly higher with application of $\mathrm{RDF}+\mathrm{FYM}+\mathrm{ZnSO}_{4} @ 20 \mathrm{~kg}$ $\mathrm{ha}^{-1}+$ Borax@2 $\mathrm{kg} \mathrm{ha}^{-1}$ at harvest which was on par with application of RDF + FYM + $\mathrm{ZnSO}_{4} @ 20 \mathrm{~kg} \mathrm{ha}^{-1}+$ Borax @ $1 \mathrm{~kg} \mathrm{ha}^{-1}$ (76 and $161 \mathrm{~g} \mathrm{ha}^{-1}$ respectively), RDF + FYM + $\mathrm{ZnSO}_{4} @ 10 \mathrm{~kg} \mathrm{ha}^{-1}+$ Borax @ $2 \mathrm{~kg} \mathrm{ha}^{-1}$ (76 and $159 \mathrm{~g} \mathrm{ha}^{-1}$ respectively) and RDF + FYM + $\mathrm{ZnSO}_{4} @ 10 \mathrm{~kg} \mathrm{ha}{ }^{-1}+$ Borax @1 kg ha ${ }^{-1}$
(72 and $155 \mathrm{~g} \mathrm{ha}^{-1}$ respectively) (Table 2). The higher dry matter production as discussed earlier owing dominant role played by zinc in improving the photosynthetic ability and assimilating capacity of crop by being a component in various enzymatic and other biochemical reactions. This might be due to increase in zinc availability because of availability of macronutrients and micronutrients to the plant. Similar results were also observed by Mankar et al., (2004).

Application of zinc and boron individually or in combination increased the uptake of boron by the crop significantly (Table 2). The highest boron uptake was recorded in the treatment receiving soil application of $\mathrm{ZnSO}_{4}$ @ $25 \mathrm{~kg} \mathrm{ha}^{-1}$ along with borax @ $2 \mathrm{~kg} \mathrm{ha}^{-1}$ in seed $\left(29 \mathrm{~g} \mathrm{ha}^{-1}\right)$ and stalk (47 $\left.\mathrm{g} \mathrm{ha}^{-1}\right)$ which was on par with application of RDF + FYM + $\mathrm{ZnSO}_{4} @ 20 \mathrm{~kg} \mathrm{ha}^{-1}+$ Borax @ $1 \mathrm{~kg} \mathrm{ha}^{-1}(28$ and $47 \mathrm{~g} \mathrm{ha}^{-1}$ respectively) and RDF + FYM + $\mathrm{ZnSO}_{4} @ 10 \mathrm{~kg} \mathrm{ha}^{-1}+$ Borax @ $2 \mathrm{~kg} \mathrm{ha}^{-1}(28$ and $47 \mathrm{~g} \mathrm{ha}^{-1}$ respectively) (Table 2) over RDF alone (15 and $24 \mathrm{~g} \mathrm{ha}^{-1}$ respectively). This may be probably due to increase in availability and absorption of boron, when boron was applied to deficit soil in the nutrient. The increased uptake might have increased the yield. Several workers have reported increased boron uptake due to boron application (Singh et al., 1994; Singh and Dixit, 1994; Cutcliffe and Gupta, 1980). Further synergistic effect was noticed between boron and zinc with respect to uptake and yield.

\section{Quality of mustard}

Among different treatments higher oil yield (731 $\mathrm{kg} \mathrm{ha}^{-1}$ ) was recorded with the application of $\mathrm{RDF}+\mathrm{FYM}+\mathrm{ZnSO}_{4} @ 20 \mathrm{~kg}$ $\mathrm{ha}^{-1}+$ Borax @2 kg ha ${ }^{-1}$ at harvest which was on par with application of RDF + FYM + $\mathrm{ZnSO}_{4} @ 20 \mathrm{~kg} \mathrm{ha}^{-1}+$ Borax @ $1 \mathrm{~kg} \mathrm{ha}^{-1}$ (718 $\mathrm{kg} \mathrm{ha}^{-1}$ ) and $\mathrm{RDF}+\mathrm{FYM}+\mathrm{ZnSO}_{4} @ 10 \mathrm{~kg}$ 
$\mathrm{ha}^{-1}+$ Borax @ $2 \mathrm{~kg} \mathrm{ha}^{-1}\left(714 \mathrm{~kg} \mathrm{ha}^{-1}\right)$. This was mainly due to higher seed yield (1973 kg $\mathrm{ha}^{-1}, 1940 \mathrm{~kg} \mathrm{ha}{ }^{-1}$, and $1929 \mathrm{~kg} \mathrm{ha}^{-1}$, respectively) and oil content (37.08, 37.06 and $37.03 \%$, respectively). The higher oil content due to synthesis of more glucosides, which produces sulphur rich amino acids like cysteine and methionine, thioglucoside and synthesis of amino acids ultimately increased the oil content in seed. Bhat et al., (2007) and Muhammad et al., (2013) also reported higher oil yield and oil content with application of zinc and boron in mustard (Table 3 ).

\section{References}

Anonymous, 2017, Area coverage, production and yield of oil seeds rabi and kharif season in India. www.indiastat.com.

Bhat, M. A., Singh, R. and Kahli, A., 2007, Effect of integrated use of farm yard manure and fertilizer nitrogen with and without sulphur on yield and quality of Indian mustard (Brassica juncea L.). $J$. Indian Soc. Soil Sci., 55: 224-226.

Cutcliffe, J. A. and Gupta, U. C., 1980, Effect of added N, P and $\mathrm{K}$ on leaf tissue B concentration and uptake of three vegetable crops. Canada J. Plant Sci., 60: 571-576.

Jackson, M. L., 1973, Soil Chemical Analysis, Prentice Hall of India, Pvt. Ltd., New Delhi, p. 120.

Mankar, S. M., Deotale, R. D., Wandile, R. M. and Dighe, R. S., 2004, Post-harvest studies in mustard as influenced by foliar application of zinc sulphate. $J$. Soil Crops, 14: 83-86.

Muhammad, T., Sharjeel, A. and Muhammad,
I., 2013, Effect of foliar application of boron on yield and quality of sunflower (Helianthus annuus L.). Crop Environ, 4(1): 23-27.

Pulakeshi, H. B. P., Patil, P. L., Dasog, G. S., Radder, B, M., Bidari, B. I. and Mansur, C. P., 2012, Mapping of nutrient status by geographic information system in Mantagan village under Northern transition zone of Karnataka. Karnataka J. Agric. Sci., 25(3): 332 - 335.

Rani, P. L. and Reddy, M. M., 1993, Effect of nitrogen and boron on yield components, yield and oil content of sunflower (Helianthus annus L.). J. Res. Andhra Pradesh Agric. Univ., 21(1): 39-41.

Shaker, T. and Mohammed, R., 2011, Effect of different levels and timing of boron foliar application on growth, yield and quality of sunflower (Helianthus annuus L.) genotypes. Mesopotamia J. Agric., 39(3): 16-26.

Singh, D., Chhonkar, P. K. and Dwivedi, B. S., 2010, Methods of soil, plant and water analysis. Westville publishing house, New Delhi, p.185.

Singh, V. and Dixit, H. C., 1994, Response of cauliflower to boron and iron application. Fert. News, 39(7): 25-26.

Singh. V., Dixit, H. C. and Rathode, S. V. S., 1994, Effect of applied P and B on the uptake and yield in cauliflower. Prog. Hort., 26(1): 53-56.

Venkatakrishnan, A. S. and Balasubramaniam, N., 1996, Yield maximization in sunflower. Madras Agric. J., 83(12): 791-792.

\section{How to cite this article:}

Shanoor Nadaf and Chandranath, H.T. 2019. Effect of Zinc and Boron on Nutrient Uptake, Yield and Quality of Mustard under Rainfed Condition. Int.J.Curr.Microbiol.App.Sci. 8(06): 2490-2495. doi: https://doi.org/10.20546/ijcmas.2019.806.298 